\title{
Factors controlling January-April rainfall over southern India and Sri Lanka
}

\author{
J. Vialard $\cdot$ P. Terray $\cdot$ J.-P. Duvel $\cdot$ \\ R. S. Nanjundiah $\cdot$ S. S. C. Shenoi • \\ D. Shankar
}

Received: 23 December 2009/Accepted: 18 December 2010/Published online: 15 January 2011

(C) Springer-Verlag 2011

\begin{abstract}
Most of the annual rainfall over India occurs during the Southwest (June-September) and Northeast (October-December) monsoon periods. In March 2008, however, Southern peninsular India and Sri Lanka received the largest rainfall anomaly on record since 1979, with amplitude comparable to summer-monsoon interannual anomalies. This anomalous rainfall appeared to be modulated at intraseasonal timescale by the Madden Julian Oscillation, and was synchronous with a decaying La Niña event in the Pacific Ocean. Was this a coincidence or indicative of a teleconnection pattern? In this paper, we explore factors controlling rainfall over southern India and Sri Lanka between January and April, i.e. outside of the southwest and northeast monsoons. This period accounts for 20\% of annual precipitation over Sri Lanka and 10\% over the southern Indian states of Kerala and Tamil Nadu. Interannual variability is strong (about $40 \%$ of the JanuaryApril climatology). Intraseasonal rainfall anomalies over
\end{abstract}

J. Vialard $(\varangle) \cdot$ P. Terray

Laboratoire d'Océanographie Expérimentation et Approches Numériques (LOCEAN), Case 100, CNRS, IRD, Université Pierre et Marie Curie, 75232 Paris Cedex 05, France

e-mail: jv@locean-ipsl.upmc.fr

J. Vialard · D. Shankar

National Institute of Oceanography, Dona Paula, Goa, India

J.-P. Duvel

Laboratoire de Météorologie Dynamique, CNRS, Paris, France

R. S. Nanjundiah

Center of Atmospheric and Oceanic Sciences, IISc, Bangalore, India

S. S. C. Shenoi

Indian National Centre for Ocean Information Services, Hyderabad, India southern India and Sri Lanka are significantly associated with equatorial eastward propagation, characteristic of the Madden Julian Oscillation. At the interannual timescale, we find a clear connection with El Niño-Southern Oscillation (ENSO); with El Niños being associated with decreased rainfall (correlation of -0.46 significant at the $98 \%$ level). There is also a significant link with local SST anomalies over the Indian Ocean, and in particular with the inter-hemispheric sea surface temperature (SST) gradient over the Indian Ocean (with colder SST south of the equator being conducive to more rainfall, correlation of 0.55 significant at the $99 \%$ level). La Niñas/cold SSTs south of the equator tend to have a larger impact than El Niños. We discuss two possible mechanisms that could explain these statistical relationships: (1) subsidence over southern India remotely forced by Pacific SST anomalies; (2) impact of ENSO-forced regional Indian Ocean SST anomalies on convection. However, the length of the observational record does not allow distinguishing between these two mechanisms in a statistically significant manner.

Keywords Rainfall interannual variability over India · El Niño/Southern Oscillation · Madden-Julian Oscillation ·

Teleconnections

\section{Introduction}

About $90 \%$ of the annual rainfall over India falls during the southwest (June to September) and northeast (October to December) monsoons. These two monsoons have a great influence over the livelihoods of over one billion people living in India and Sri Lanka. There is, for example, a clear link between the monsoon rainfall and rice production in India (see e.g. Webster et al. 1998 for a description of the 
socio-economic impacts of the monsoon over India). This has prompted numerous studies on factors controlling the variations of the southwest monsoon at both interannual and intraseasonal timescales.

The seminal work of Sir Gilbert Walker (e.g. Walker and Bliss 1932) both pointed out the link between the Indian monsoon and sea level pressure at Darwin, Australia, and led to the discovery of what would be later known as El Niño/Southern Oscillation (ENSO). Many studies then illustrated the links between ENSO and the southwest monsoon, suggesting that anomalously warm temperatures in the central Pacific during El Niño induce anomalous subsidence further west, over India, which tend to diminish convection and rainfall (Shukla and Paolino 1983; Rasmusson and Carpenter 1983; Ropelewski and Halpert 1987, 1989; Nageswara Rao 1999). This relation between ENSO and the southwest monsoon however appears to have weakened during recent decades (e.g. Krishna Kumar et al. 1999). There is also an influence of ENSO on the northeast monsoon (Ropelewski and Halpert 1987, 1989; Nageswara Rao 1999; Kripalani and Kumar 2004; Kumar et al. 2007; Revadekar and Kulkarni 2008), with an El Niño being associated with increased northeast monsoon rainfall over southern India and Sri Lanka between October and December. This relation seems to have strengthened during the last decades, unlike the ENSO-southwest monsoon teleconnection (Zubair and Ropelewski 2006; Kumar et al. 2007), and is generally attributed to ENSO-induced changes in the Walker circulation.

In addition to atmospheric teleconnections associated with changes in the Walker circulation, there is also the possibility that local SST changes in the Indian Ocean could affect the monsoon. There is clear SST interannual variability in the Indian Ocean. One part is associated with a warming of the Indian Ocean during El Niños (cooling during La Niñas), remotely forced by increased subsidence (ascendance) over the Indian Ocean (Klein et al. 1999; Lau and Nath 2000). Another part is associated with an intrinsic mode of variability of the Indian Ocean. As ENSO in the Pacific, the "Indian Ocean dipole" (IOD; e.g. Saji et al. 1999; Webster et al. 1999; Murtugudde et al. 2000) develops as the result of an ocean-atmosphere coupled instability, and leads to an east-west dipole in SST and associated zonal wind anomaly. While there is a tendency of the IOD to occur simultaneously with El Niño, this ENSO influence is not a one-to-one relationship (e.g. Yamagata et al. 2004).

Several studies have shown clear links between Indian Ocean SST anomalies (either intrinsic or linked to ENSO) and the Indian monsoons (see Schott et al. 2009 for a review). The maximum IOD SST perturbations occur during the northeast Monsoon. Zubair et al. (2003) investigated their link and suggested a role of Indian Ocean SSTs in modulating the northeast monsoon. SST anomalies that develop in the southwestern tropical Indian Ocean and in the Somalia upwelling during the course of an IOD or after an ENSO event impact rainfall over the Western Ghats of India during the following southwest monsoon (Izumo et al. 2008; Vecchi and Harrison 2004). Annamalai et al. (2005) showed that Indian Ocean Sea Surface Temperature Anomalies (SSTAs) affect the atmospheric integrated moisture and can induce an advance or delay in the onset of the southwest monsoon. Finally, recent studies illustrate how both ocean dynamical processes (Du et al. 2009) and wind-evaporation-SST feedback (Wu et al. 2008; Kawamura et al. 2001) tend to induce an asymmetric SST response to ENSO, with warm SSTAs south of the equator during spring, which migrate to the northern Indian Ocean in summer. These SSTAs are associated with an asymmetric atmospheric response in spring, with reduced precipitation over the Arabian Sea, Bay of Bengal and South China Sea (Xie et al. 2009; Wu et al. 2008).

In addition to interannual anomalies, the other clear signals in monsoon rainfall are intraseasonal variations, with "active" and "break" spells of the Indian monsoon. During summer, in addition to synoptic variability, there is indeed a clear modulation of the monsoon at two preferential timescales around 10-20 and 30-60 days (e.g. Goswami 2005; Waliser 2006). The 30-60 day modulation of monsoon rainfall is associated with a clear northward propagation of convective anomalies over India and the Bay of Bengal. The main mode of atmospheric intraseasonal variability is the Madden-Julian Oscillation (hereafter MJO, see e.g. Zhang 2005 for a review), which is rather associated with eastward propagation of convective anomalies along the convergence zone. Active and break cycles of the monsoon tend to be associated with the MJO over the Indian Ocean, although this relation is not systematic (see, e.g. Goswami 2005 for a discussion). MJO composites indeed show northward propagation of convective perturbations over India during summer (e.g. Wheeler and Hendon 2004), characteristic of the monsoon active and break phases.

There have thus been numerous studies of the factors controlling interannual and intraseasonal variability of the northeast and southwest monsoon. In contrast, there are almost no studies of the factors controlling the rain over southern India and Sri Lanka outside of the two monsoons season (roughly between January and May). Most of the studies investigating the impacts of the ENSO cycle on rainfall over Asia and the Western Pacific during spring have focused on the Indonesian and east Asian monsoon, where signals are strongest (see, e.g. Wang et al. 2000), but not on India. The recent studies of Wu et al. (2008) and Xie et al. (2009) focus on large-scale rainfall patterns over the 
Indian Ocean during spring, but do not study specifically rainfall anomalies over southern India and Sri Lanka. Although the total rainfall during this period is rather low (around $10 \mathrm{~cm}$ over southern India and $30 \mathrm{~cm}$ over Sri Lanka), it accounts for $20 \%$ of annual precipitation over Sri Lanka and $10 \%$ over the southern Indian states of Kerala and Tamil Nadu (see Fig. 1a, b). Interannual variability is strong (about $40 \%$ of the mean, Fig. 1c). This can easily be understood since the southern tip of India and Sri Lanka lies at the fringe of the Inter-Tropical Convergence Zone (ITCZ) at that time: small latitudinal shifts of the ITCZ can thus result in rather large precipitation anomalies in this region during spring. Another motivation is given by a recent event. In March 2008, there was a strong rainfall anomaly over most of peninsular India, south of $20^{\circ} \mathrm{N}$ (Fig. 2a). This was the largest anomaly over southern India and Sri Lanka (hereafter SISL) since 1979, even when monsoon month anomalies are included (Fig. 3). There was also a clear rainfall anomaly in April 2008, although mostly over the Bay of Bengal, and there was a decaying La Niña in the Pacific Ocean and cold SST anomalies in the southern Indian Ocean (see Fig. 2b, c). Are those two large anomalous rain-events in March and April 2008 connected with the decaying La Niña in the Pacific Ocean and/or local SSTAs in the Indian Ocean? In this paper, we will investigate the factors controlling rainfall over SISL during January-April.

The paper is constructed as follows. Section 2 presents the data and methods used in this paper. In Sect. 3, we present the case of the March 2008 rainfall anomaly as an example. We show that the March 2008 rainfall anomalies over India were synchronous with a La Niña in the Pacific Ocean and a cold south Indian Ocean. Rainfall anomalies over SISL also appeared to be modulated by the MJO at the intraseasonal timescale. In Sect. 4, we explore teleconnections associated with winter and spring rainfall over south peninsular India. We show that it is modulated by the MJO at intraseasonal timescale, and significantly correlated with ENSO at the interannual timescale. We also explore links between January-April SISL rainfall and SST anomalies in the Indian Ocean and find a significant connection with the interhemispheric SST gradient. A summary and discussion of these results are provided in Sect. 5, which includes hypotheses of mechanisms and links of our results with other recent studies.

\section{Data and methods}

\subsection{Data}

The rainfall dataset we use is the Global Precipitation Climatology Project (GPCP; Huffman et al. 1997). In most (a) Rainfall for Jan-April

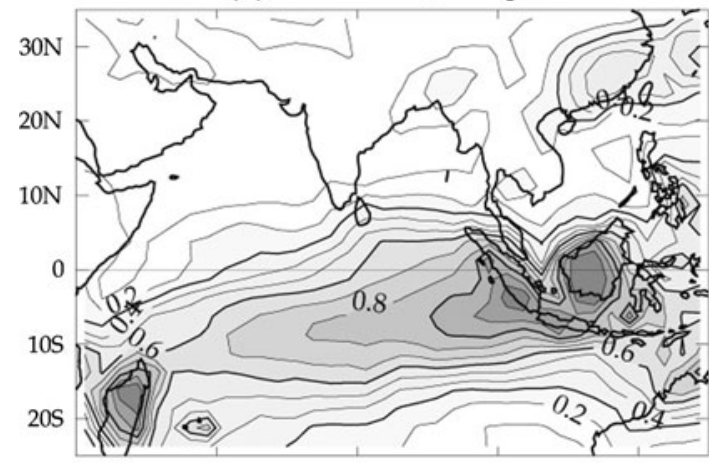

(b) \% of annual Rainfall in Jan-April

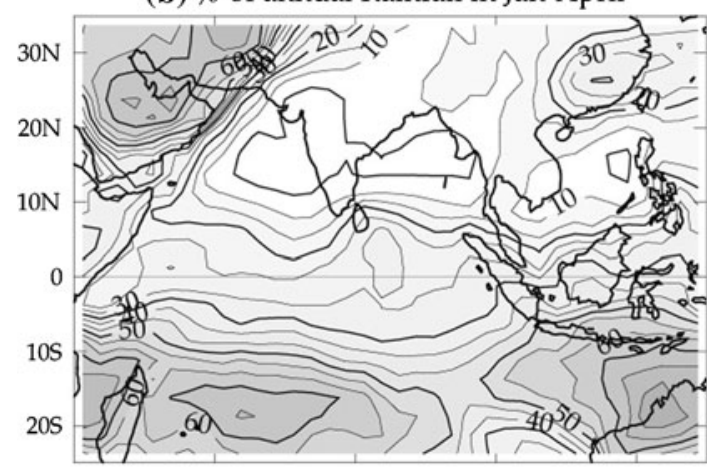

(c) Std of Jan-April rainfall anomaly

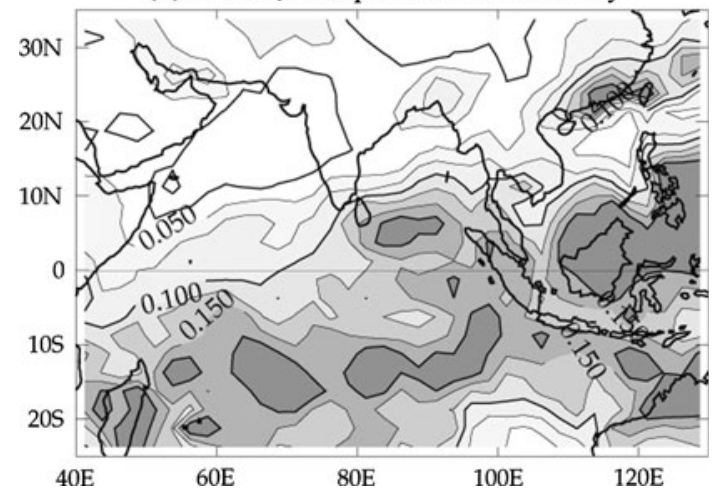

Fig. 1 a January-April climatological rainfall from GPCP product (contour interval $0.1 \mathrm{~m}$ ). b Percentage of climatological annual rainfall falling between January and April (contour interval 5\%). c Standard-deviation of January-April interannual monthly rainfall anomalies (contour interval $0.025 \mathrm{~m}$ )

of the paper, we use the pentad data, available on a $2.5^{\circ}$ grid since January 1979. However, we use the daily data on a $1^{\circ}$ grid (Huffman et al. 2001) to illustrate the March 2008 anomalous rain event. We use pentad data rather than monthly data since, as we will show later, the rainfall over India is modulated at intraseasonal timescale by the MJO. Using 5-day data allows filtering out the MJO signal by applying a 90-day low-pass filter (see Sect. 2.2), hence avoiding the strong aliasing on monthly data, and resulting in a better isolation of ENSO teleconnections. We will also use the high-resolution gridded daily precipitation dataset 
Fig. 2 Map of a March 2008 and b April 2008 rainfall anomalies from GPCP product (contour interval $3 \mathrm{~mm}$ day $^{-1}$, shading for rainfall above normal), c Map of SST anomaly for March $2008\left({ }^{\circ} \mathrm{C}\right.$, contour interval $0.5^{\circ} \mathrm{C}$, shading for negative values) from Reynolds product. The $5^{\circ} \mathrm{N}-20^{\circ} \mathrm{N}, 70^{\circ} \mathrm{E}-$ $85^{\circ} \mathrm{E}$ region, encompassing south India and Sri Lanka is indicated for future reference (a) March 2008 precip anom

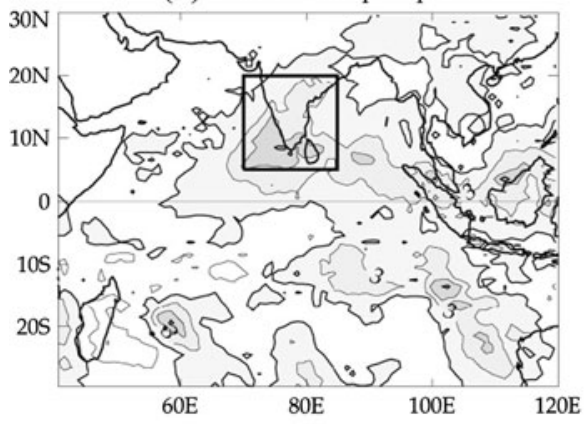

(b) April 2008 precip anom

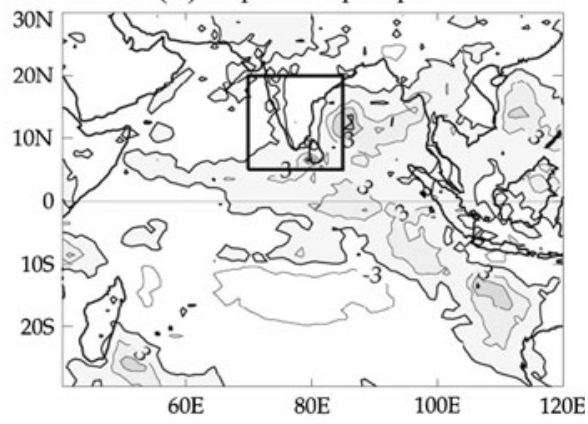

(c) March 08 Reynolds SSTA

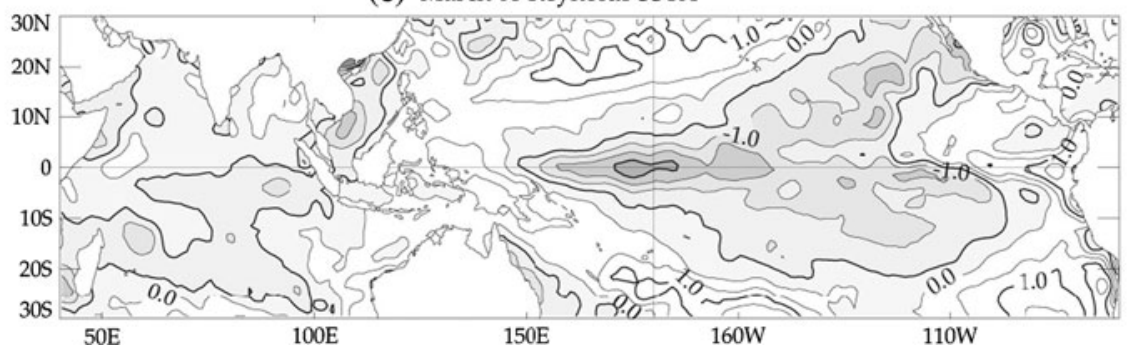

produced by the India Meteorological Department (Rajeevan et al. 2006). This is probably the best available rainfall dataset for India. Hence, we repeated some of the diagnostics made with GPCP data with the IMD data, to check that the ENSO-rainfall teleconnection is robust when considering only southern India and the late winter and early spring season.

We use the monthly gridded SST product from Reynolds et al. (2002). This product is available on a $1^{\circ}$ regular grid from November 1981 to present. We use velocity potential at sigma level (sigma $=0.22$, i.e. very close to the $225 \mathrm{hPa}$ level) from the NCEP-NCAR reanalysis (Kalnay et al. 1996) as a proxy for the Walker circulation. This proxy has also been used in previous studies (e.g. Krishna Kumar et al. 1999; Zubair and Ropelewski 2006). This data was downloaded from the Climate Data Centre (CDC) website at http://www.cdc.noaa.gov/. We use monthly data from 1958 to present at a resolution of $1.875^{\circ}$.

Scatterometer winds from Quickscat will be used to illustrate the wind climatology during different seasons over the Indian Ocean. The wind product produced by CERSAT (IFREMER) is available at http://www.ifremer. fr/cersat/en/index.htm.

To study the influence of the MJO, we have used the index developed by Wheeler and Hendon (2004). This index is available online at http://www.bom.gov.au/bmrc/ clfor/cfstaff/matw/maproom/RMM/.

\subsection{Methods}

In this paper, we will mainly use linear-regression diagnostics to illustrate statistical relations between existing climate indices and rainfall over south India. All the regression analyses in this paper use standardized indices (i.e. of standard deviation equal to 1), in order to isolate the amplitude of rainfall anomalies associated with, e.g. a "typical" amplitude El Niño event.

The regression analyses aiming at isolating the influence of El Niño use a rather classical index: the December value of the average Nino3.4 region $\left(120^{\circ} \mathrm{W}-170^{\circ} \mathrm{W}, 5^{\circ} \mathrm{N}-5^{\circ} \mathrm{S}\right)$ SST normalized anomaly. The list of years obtained with this criterion is slightly different than, e.g. the list of ENSO years as defined by the Climate Prediction Centre (CPC) (and available from http://www.cpc.noaa.gov/products/ analysis_monitoring/ensostuff/ensoyears.shtml) but regressions performed using both definitions look very similar. The other climate indices used in this paper will be introduced in more detail later, but we will mention them quickly here. We use the same index as Wu et al. (2008) to isolate the spring antisymmetric mode in rainfall (principal component of the first EOF of average March-May precipitation over the Indian Ocean). We tested that this index is weakly modified when applied over a different season (January-April instead of March-May) and different period (1982-2008 in this study against 1979-2005 in Wu et al. 2008) and use the index derived over March-May from 1982 to 2008 in this study. We use the difference of interannual anomalies of average SST within $\left(65^{\circ} \mathrm{E}-100^{\circ} \mathrm{E}\right.$, $\left.10^{\circ} \mathrm{N}-20^{\circ} \mathrm{N}\right)$ and $\left(75^{\circ} \mathrm{E}-105^{\circ} \mathrm{E}, 8^{\circ} \mathrm{S}-0^{\circ}\right)$ to estimate the influence of anomalies of the interhemispheric SST gradient (see later in the text for justification of the choice of these regions). The southwestern Indian Ocean (hereafter SWIO, Annamalai et al. 2005) is an important region for the Indian Ocean climate; for this region we use the same 
SST index as given in Annamalai et al. (2005) (SST anomalies averaged over $\left.50^{\circ} \mathrm{E}-70^{\circ} \mathrm{E}, 17.5^{\circ} \mathrm{S}-7.5^{\circ} \mathrm{S}\right)$. Finally, we also use the index of the "Subtropical Dipole mode" introduced by Behera and Yamagata (2001): SST anomalies differences between the $\left(90^{\circ} \mathrm{E}-100^{\circ} \mathrm{E}, 28^{\circ} \mathrm{S}-\right.$ $\left.18^{\circ} \mathrm{S}\right)$ and $\left(55^{\circ} \mathrm{E}-65^{\circ} \mathrm{E}, 37^{\circ} \mathrm{S}-27^{\circ} \mathrm{S}\right)$ regions.

All the analyses made in this paper are based on pentad data. A daily climatology is constructed from the full record average of daily-interpolated pentad data, with a 45-day boxcar filter in order to remove aliasing from high frequencies. Interannual anomalies were first computed for these pentad data by taking the difference between the raw data and this climatology. Time filtering was then used to separate the intraseasonal (10-90 days) and seasonal (90 day+) components of these interannual anomalies. We used several types of filters (simple filter based on a reverse Fourier transform, digital filtering, Hanning filter) with a minor influence on our results. In the rest of the paper, we use the simple Fourier filtering. We will refer the 90-day low-passed anomalies with respect to the climatology as interannual anomalies. We define intraseasonal anomalies as the 10-90 day filtered anomalies with respect to the climatology. For all the significance computations, the number of degrees of freedom has been taken as the number 90 days-samples for intraseasonally filtered data, and number of years for interannual anomalies.

All the analyses have been made both on raw and detrended data, with very similar results. Some studies have shown changes in teleconnections patterns (e.g. southwest monsoon and ENSO) after the end of the seventies. All of the analyses in this paper are focusing on the recent period, and are performed on the longest dataset available (1979-2007 or 1982-2007). We chose to exclude 2008 from these analyses, because of the very strong amplitude signal that year (see next section). Similar analyses up to 2009 included give similar results (with larger amplitude signals).

\section{The case of March 2008}

There was a clear rainfall anomaly over the central and eastern Indian Ocean in March and April 2008 (Fig. 2a, b), with significant regions of monthly rainfall above $90 \mathrm{~mm}$. While rainfall anomalies were largely located over the ocean in April, there was a significant rainfall anomaly over land (peninsular India and Sri Lanka) in March 2008. The largest rainfall anomalies over peninsular India generally occur during the southwest monsoon. The March 2008 rainfall anomaly, however, was the largest on record over that region $(120 \mathrm{~mm}$ in 1 month) with values exceeding even those of summer months (Fig. 3). Nevertheless, even though the March 2008 case is exceptional,

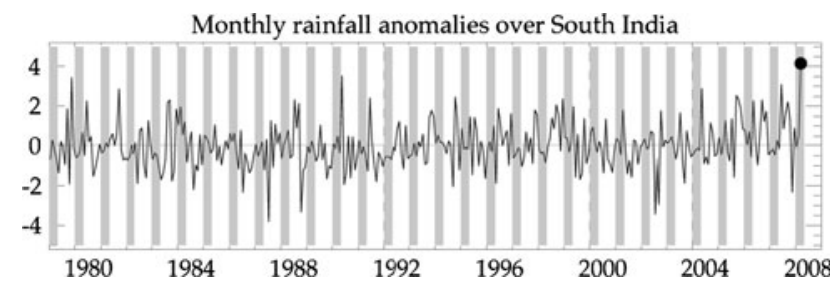

Fig. 3 Time series of monthly rainfall anomalies $\left(\mathrm{mm} \mathrm{day}^{-1}\right)$ over the $5^{\circ} \mathrm{N}-20^{\circ} \mathrm{N}, 70^{\circ} \mathrm{E}-85^{\circ} \mathrm{E}$ region, encompassing south India and Sri Lanka (outlined in Fig. 2a). A shading highlights the January-April period and a black disk indicates the March 2008 rainfall anomaly

there are other occurrences of significant monthly rainfall anomalies during January-April (Fig. 3).

The Indo-Pacific climate in March 2008 was characterized by a decaying La Niña event. In March 2008, there were still significant cold anomalies near the dateline (up to $-2^{\circ} \mathrm{C}$ anomaly, Fig. $2 \mathrm{c}$ ). There is thus a possibility that the March-April 2008 rainfall anomalies over India were in some ways linked to this La Niña in the Pacific Ocean, and we'll investigate this in the next section. But local SST anomalies over the Indian Ocean could also play some role. The usual response to a La Niña event at this time of the year is an overall cooling of the southern tropical Indian Ocean, remotely forced by increased deep atmospheric convection over the Indian Ocean (Klein et al. 1999; Lau and Nath 2000). In spring, this cooling is generally strongest south of the equator (Wu et al. 2008; Du et al. 2009; Xie et al. 2009). In March 2008, the Indian Ocean was indeed cooler over most of the basin, with the clearest cooling between $20^{\circ} \mathrm{S}$ and the equator (Fig. 2c). A positive meridional SST gradient can favour northward displacement of the ITCZ, both just before monsoon onset (Annamalai et al. 2005) and during the monsoon (Shankar et al. 2007). Figure 4a shows an estimate of the climatological interhemispheric temperature gradient over the central and eastern Indian Ocean. During normal years, the northern hemisphere becomes progressively warmer than the southern hemisphere in March and rainfall starts (Fig. 4a) to increase over southern India. In 2008, largely because of cold anomalies in the southern hemisphere, the February and March climatological gradient had reversed. Warmer temperatures were found north of the equator, with an inter-hemispheric gradient comparable to that of April during Normal years. This anomaly might have contributed to favour an early northward displacement of the ITCZ in March 2008.

Figure $4 \mathrm{~b}$ shows daily rainfall in late 2007 and early 2008 over the region outlined in Fig. 2a and b. The rain event in March 2008 was a 20-25 days spell from the 5 March until the end of the month. Figure $4 \mathrm{~b}$ indicates that the rain event of March 2008 occurs during an active phase of the MJO over the eastern Indian Ocean. Actually, Fig. 8 
(a) Interhemispheric SST gradient over BOB

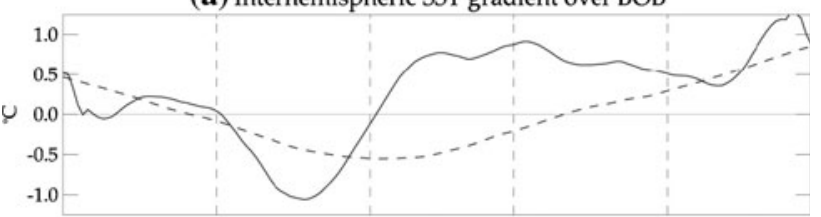

(b) Rainfall over southern India

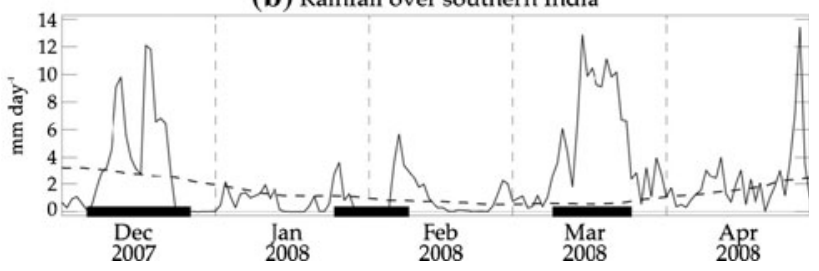

Fig. 4 a Climatological (dashed line) and late 2007-early 2008 meridional temperature gradient over the central and eastern Indian Ocean. The meridional temperature gradient is computed as SST in $70^{\circ} \mathrm{E}-95^{\circ} \mathrm{E}, 3^{\circ} \mathrm{N}-10^{\circ} \mathrm{N}$ minus the SST in $70^{\circ} \mathrm{E}-95^{\circ} \mathrm{E}, 3^{\circ} \mathrm{S}-10^{\circ} \mathrm{S}$ b Daily rainfall $\left(\mathrm{mm} \mathrm{day}^{-1}\right)$ over southern peninsular India and Sri Lanka (region highlighted in Fig. 2a) from GPCP product. The dashed line shows the long-term climatology from the same product. The time periods for which the Wheeler and Hendon (2004) MJO index has a larger amplitude than one and a phase 2, 3 or 4 (active MJO phase over the Indian ocean) has been highlighted with black marks on the time axis

from Wheeler and Hendon (2004) suggests that the averaged MJO perturbation in December-February span a large latitude range (about $15^{\circ} \mathrm{S}-10^{\circ} \mathrm{N}$ ), and could have a signature over India The rain event of March 2008 occurred simultaneously with an active phase of the MJO over the Indian Ocean. Actually, Fig. 8 from Wheeler and Hendon (2004) suggests that the MJO in December-February spans a large latitude range (about $15^{\circ} \mathrm{S}-10^{\circ} \mathrm{N}$ ), and could have a signature over India. We will investigate later if this can also be the case in March.

In the rest of the paper, we will investigate if the occurrence of a La Niña event and/or an active phase of the MJO over the eastern Indian Ocean can give a large and positive rainfall anomaly over southern India during the JFMA season.

\section{Observed teleconnections associated with winter/ spring rainfall over southern India and Sri Lanka}

\subsection{Rainfall patterns during January-April}

Before proceeding to the discussion of the link between rainfall over south India and Sri Lanka and El Niño during the dry season and the MJO, we will review briefly the structure of low-level winds and rainfall at that time of the year. Figure 5 shows the surface wind and rainfall climatology. During the southwest monsoon, the southwesterlies collect moisture over the southern Indian Ocean, Arabian
Sea and Bay of Bengal, with maximum precipitation downstream over the Western Ghats and Myanmar region (Fig. 5a). The precipitation over southern India is thus largely the result of moisture collected over the Arabian Sea by the monsoon low-level jet. During the northeast monsoon, the winds have reversed and the precipitation over South India is mostly the result of moisture collected over the Bay of Bengal by the easterlies. During January to March, the wind and rain patterns do not change much (not shown). The wind becomes more southward as the ITCZ moves southward under the effect of solar forcing. As a result, southern India receives much less moisture and only the southern part of Sri Lanka experiences rainfall (Fig. 5c). The wind pattern changes in April. With the strong and abrupt warming of the south-eastern Arabian Sea and southern Bay of Bengal (not shown; Joseph 1990; Vinayachandran and Shetye 1991), the ITCZ moves north of the equator in the central and eastern Indian Ocean, but the atmospheric circulation remains anticyclonic over the Arabian Sea. As a result, surface winds become northwesterlies at the southern tip of India and they bring moisture to these regions and significant rainfall start to occur there.

We have seen above that moisture sources and atmospheric circulation patterns appeared to be quite different during January-March and April. To characterize the rainfall interannual patterns during that period, we performed an EOF analysis of interannual GPCP rainfall anomalies separately for months from December to May (Fig. 6). The interannual variability during JFMA is strongest south of the Bay of Bengal, but it extends over the SISL region. This impact is strongest during January to March, but is also present in April.

The patterns of interannual variability are quite stable from January to April (their correlation with the JanuaryApril average pattern are 0.96, 0.98, 0.93 and 0.67, respectively). On the other hand, the patterns are markedly different for December and May (their correlation with the January-April average pattern are 0.36 and -0.6 , respectively). Because of the similarity of interannual rainfall anomalies over the Northern Indian Ocean during the January to April months, we will generally use the January-April average for our analyses in the rest of the paper.

\subsection{MJO influence}

We will first review the potential influence of the MJO on SISL precipitation. The March 2008 case suggests that rainfall tends to occur preferably during active phase of the MJO over the Indian Ocean (i.e. the strong rainfall event over the SISL in March 2008 is related to a large-scale convective intraseasonal event). Similarly, Fig. 8 from Wheeler and Hendon (2004) shows that active phase of the 
Fig. 5 Climatological rainfall from GPCP product (contour interval $2 \mathrm{~mm} \mathrm{day}^{-1}$, shading above $2 \mathrm{~mm} \mathrm{day}^{-1}$ ) and climatological winds from Quickscat (see plot for scale) for a June-September (southwest monsoon), b October-

November (northeast monsoon), c January-March, d April (a) JJAS

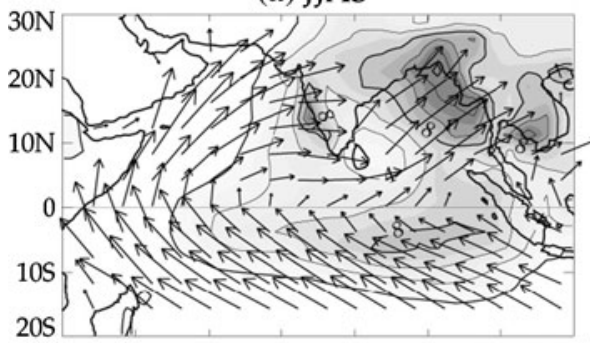

c) JFM

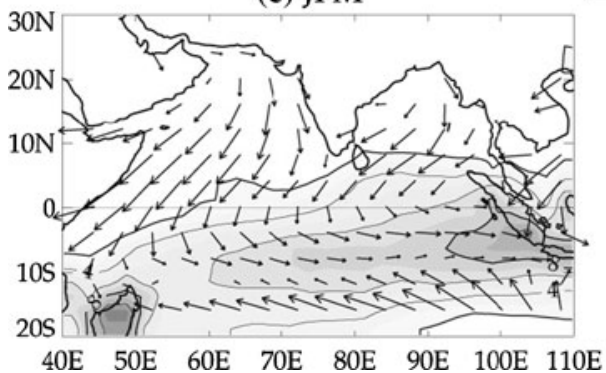

$\begin{array}{llllllll}40 \mathrm{E} & 50 \mathrm{E} & 60 \mathrm{E} & 70 \mathrm{E} & 80 \mathrm{E} & 90 \mathrm{E} & 100 \mathrm{E} & 110 \mathrm{E}\end{array}$ (b) $\mathrm{ON}$

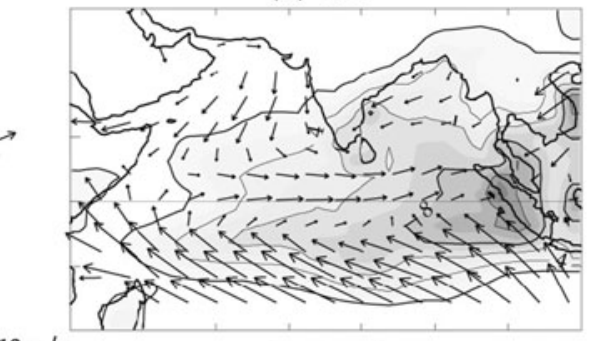

(d) April

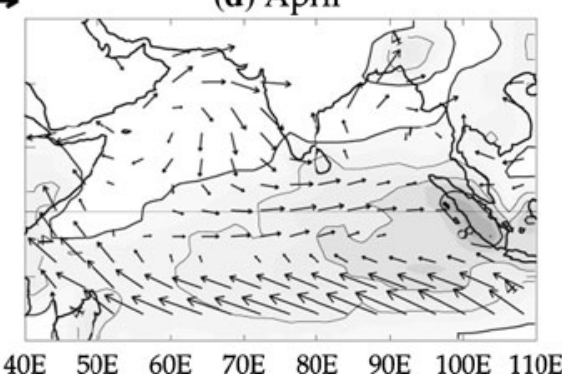

(a) $\mathrm{r}(\mathrm{Dec}, \mathrm{JFMA})=0.36$

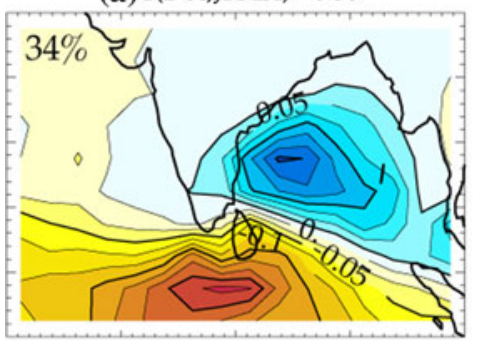

(d) $\mathrm{r}(\mathrm{Mar}, \mathrm{JFMA})=0.93$

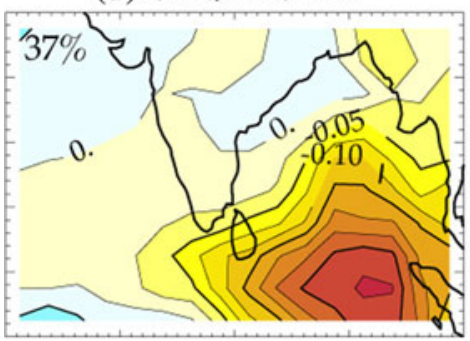

(b) $\mathrm{r}(\mathrm{Jan}, \mathrm{JFMA})=0.96$

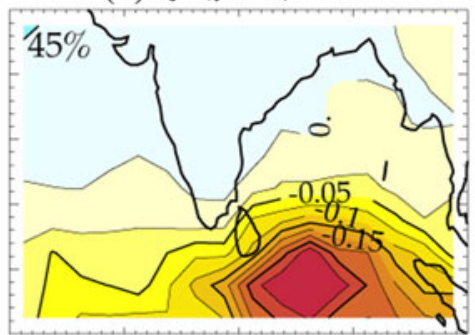

(e) $\mathrm{r}($ Apr,JFMA $)=0.67$

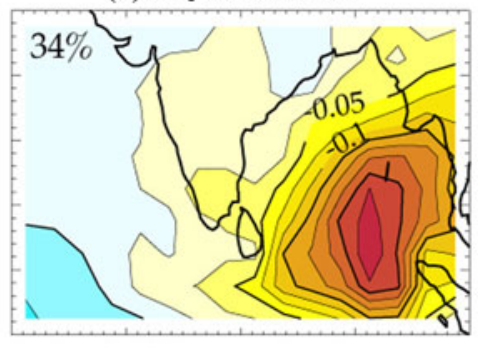

$\begin{array}{lllll}-0.2 & -0.1 & 0 . & 0.1 & 0.2\end{array}$ (c) $\mathrm{r}(\mathrm{Feb}, \mathrm{JFMA})=0.98$

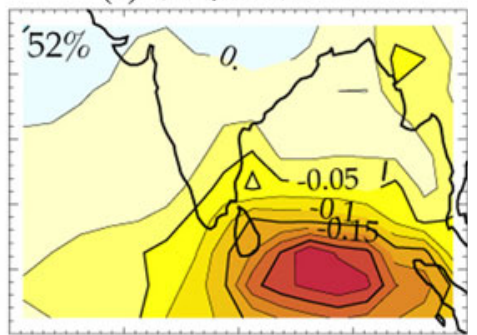

(f) $\mathrm{r}$ (May,JFMA) $=-0.60$

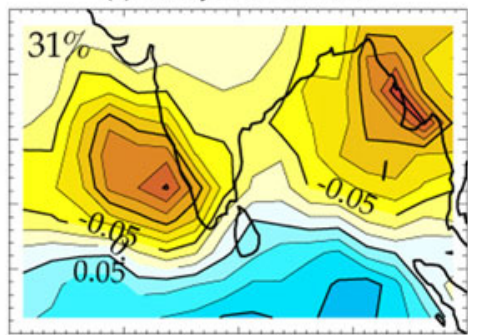

Fig. 6 Empirical orthogonal function analysis of the 90-day lowpassed filtered GPCP rainfall anomalies for the months of a December, b January, c February, d March, e April, and f May. The spatial correlation of each pattern with the pattern for the January-April rainfall average is indicated above each plot. The normalization is the same in each plot but the unit is arbitrary
MJO is associated with low outgoing longwave radiation (i.e. more convection) over southern India during December-February. Conversely, break phases of the MJO over the Indian Ocean seem to be associated with less convection. Hence, we repeated the composite analysis of Wheeler and Hendon (2004), but using GPCP pentad rainfall (rather than OLR) and focusing on the JanuaryMarch period.

Figure $7 \mathrm{c}$ shows that there is a statistically significant impact of the MJO on rainfall over southern India with phase 3 (active convection over the Indian Ocean) associated with $\sim 1.5 \mathrm{~mm} \mathrm{day}^{-1}$ additional rainfall over south India while phases 6 and 7 (pause of convection over the Indian Ocean) associated with small negative $\left(\sim-.5 \mathrm{~mm}\right.$ day $\left.^{-1}\right)$ rainfall anomalies. The composite map of phase 3 of the MJO (Fig. 7a) shows maximum rainfall anomalies over the Indian Ocean, south of the Bay of Bengal; with the fringe of the anomalous regions affecting SISL. The probability of strong rainfall, however, seems to suggest that while the probability is high over the ocean, it 
is only slightly so over the southern tip of India (Fig. 7b). When Fig. 7 is repeated separately for all months between January and April, the strongest impact on SISL rainfall is found in January-February.

Time series of precipitation over southern India and the Bay of Bengal $\left(75^{\circ} \mathrm{E}-95^{\circ} \mathrm{E}, 10^{\circ}-12^{\circ} 30^{\prime} \mathrm{N}\right)$ display episodic rainfall events of $\sim 20-30$ days (Fig. 8). In order to understand the large-scale context of these rainfall events, we composited intraseasonally filtered GPCP rainfall averaged between $10^{\circ} \mathrm{N}$ and $10^{\circ} \mathrm{S}$ for all rain events longer than 20 days and with more than $1 \mathrm{~mm}$ day $^{-1}$ precipitation at different lags. Episodic rainfall events of $\sim 20-30$ days tend to be associated with alternating planetary scale (wavenumbers 3-4) perturbation of rainfall propagating at about $4 \mathrm{~ms}^{-1}$ along the equator (Fig. 9). Episodic rainfall events over SISL in JFMA are therefore associated with planetary scale eastward propagation of equatorial rainfall anomalies characteristic of the MJO (which has a propagation speed of $\sim 5 \mathrm{~ms}^{-1}$; Zhang 2005).

As mentioned earlier, the analysis of Wheeler and Hendon (2004) suggests a relatively modest impact of the MJO over SISL rainfall at that time of the year. However, the analysis of Fig. 9 shows that when such rainfall events do occur, they tend to be associated with an equatorial MJO event, i.e. not all the MJO events result in rainfall over SISL at that time of the year, but the rainfall events seem to be, in general, associated with an active MJO phase over the Indian Ocean. This is similar to what was found during the southwest monsoon by Wang and Rui (1990) and Jones et al. (2004): the association between the MJO and rainfall over India during the monsoon exists but is not systematic. We will come back to this point in Sect. 5.

Thus, large-scale convective perturbations associated to the MJO play a role in modulating intraseasonal rainfall over southern India during January-April. We examine phenomena that are likely to modulate the interannual rainfall over the SISL region (El Niño and local SST anomalies over the Indian Ocean) in the next two sections.

\subsection{ENSO influence}

Figure 10 shows the regression coefficients of JanuaryApril rainfall over southern India with synchronous SST interannual anomalies. Figure 10 is derived from a rainfall index based on the IMD gridded dataset (i.e. rainfall over India, south of $12^{\circ} \mathrm{N}$ ), but a very similar result is obtained when considering interannual GPCP rainfall over a box encompassing Sri Lanka and South India. For comparison, Fig. 10b shows SSTAs in JFMA after the peak of El Niño. The similarity between the ENSO pattern (Fig. 7b) and the teleconnection pattern of winter/spring SISL rainfall is striking. Excess rainfall over southern India during this season is associated with a La Niña-like pattern in the tropical Pacific and cold SST between the equator and $10^{\circ} \mathrm{S}$ in the Indian Ocean. There is also a very clear and significant ENSO "horseshoe" pattern associated with rainfall over southern India in JFMA.

It is interesting to note, however, that while the patterns are quite similar over the Pacific Ocean, there are quite a few differences in patterns between Fig. 7a and $b$ over the Indian Ocean. This suggests that local SSTAs over the
Fig. 7 Composite of intraseasonally filtered (10-90 days) January-March GPCP rainfall, as a function of the phase of the Madden-Julian Oscillation, as indicated from the Wheeler and Hendon (2004) index. a Composite for phase 3 of the MJO (one of the active phases over the Indian Ocean, this composite is significant at the $95 \%$ level almost everywhere); b \% of chance of having rainfall in the highest quintile; c average composite rainfall over southern India and Sri Lanka (box indicated in a and $\mathbf{b}$ ) as a function of the phase of the Madden-Julian Oscillation; vertical bars indicate the $95 \%$ confidence interval (a) Composite rain, MJO phase $=3$ JFM
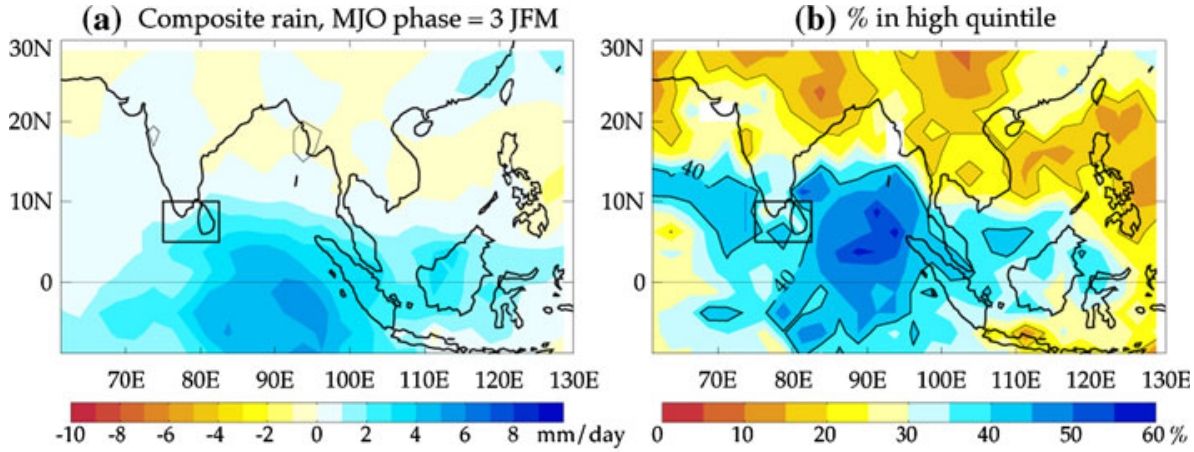

(c) Composite rain, in SISL region

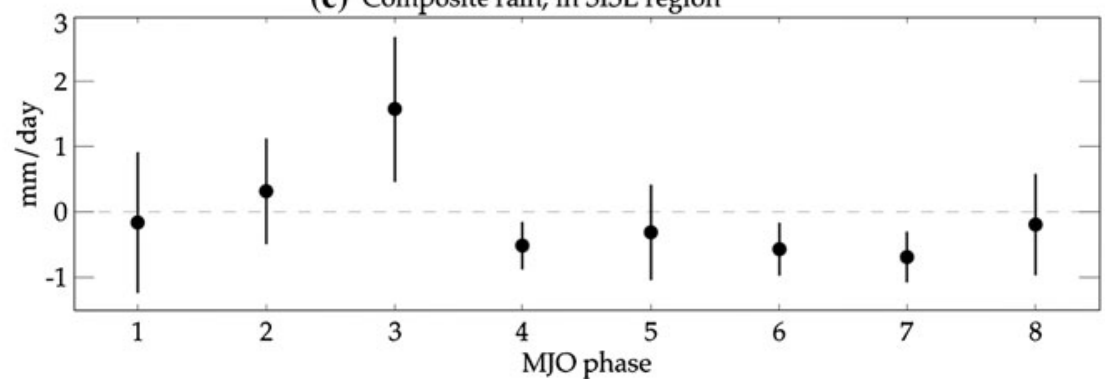




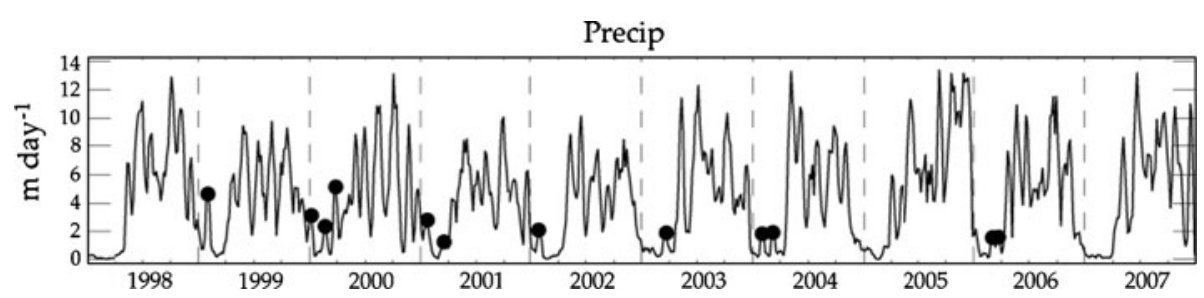

Fig. 8 Time series of pentad GPCP rainfall over southern India and the Bay of Bengal (averaged over $75-95^{\circ} \mathrm{E}$ in the $10^{\circ} \mathrm{N}-12^{\circ} 30^{\prime} \mathrm{N}$ latitude band). Rain events longer than 20 days and $>1 \mathrm{~mm} \mathrm{day}^{-1}$ in

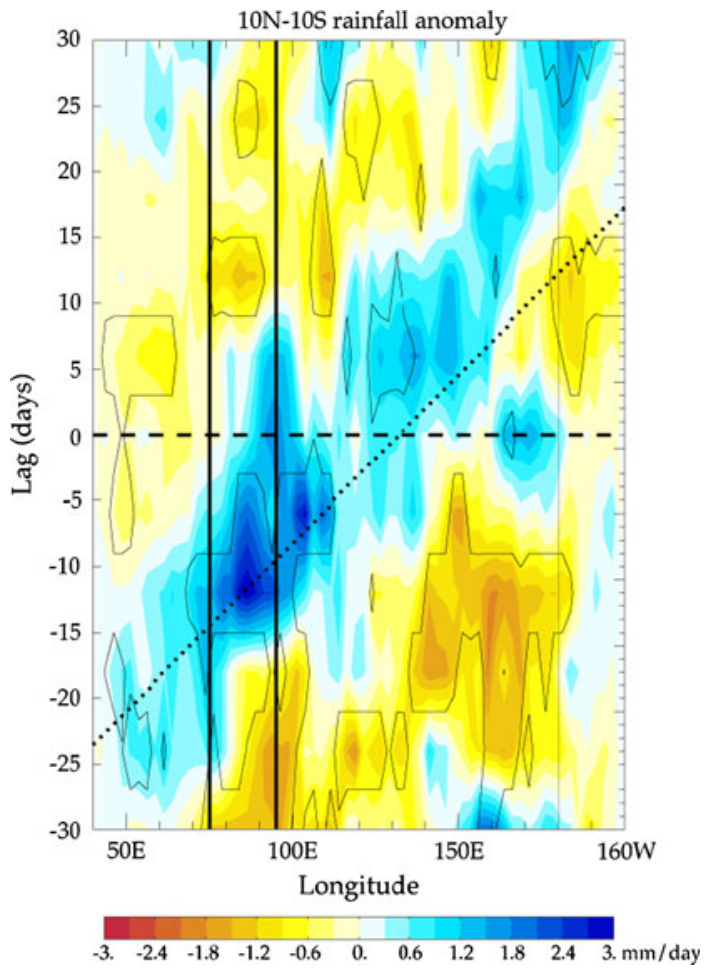

Fig. 9 Composite of intraseasonally filtered (10-90 days) JanuaryMarch GPCP rainfall, averaged between $10^{\circ} \mathrm{N}$ and $10^{\circ} \mathrm{S}$ and plotted as a function of time lag (in days). Lag 0 corresponds to the 25 rainfall events over southern India shown in Fig. 8. The contour shows area where the signal is significant at the $95 \%$ confidence level. The dotted line indicates $5 \mathrm{~ms}^{-1}$ eastward propagation (the average speed of the MJO)

Indian Ocean might be important in triggering rainfall anomalies over south India during JFMA. We will come back to this point in the Sect. 4.4.

Figure 11 shows the regression patterns of GPCP rainfall over the Indian Ocean for the Niño3.4 SSTA in December (a good proxy for ENSO; we obtain similar pictures for other commonly used ENSO indices). We show this regression for several seasons in order to compare the signals in January-April with those already discussed for other seasons in previous studies. Teleconnection patterns already discussed by other authors for both monsoons can be recognized. A significant signal appears during the southwest
JFM are marked by a circle. The time series here only shows 1998-2007 for clarity, but a total of 25 cases between 1979 and 2007 were selected to construct the composite of Fig. 9

(a) Regression of SSTA JFMA based on south India rainfall

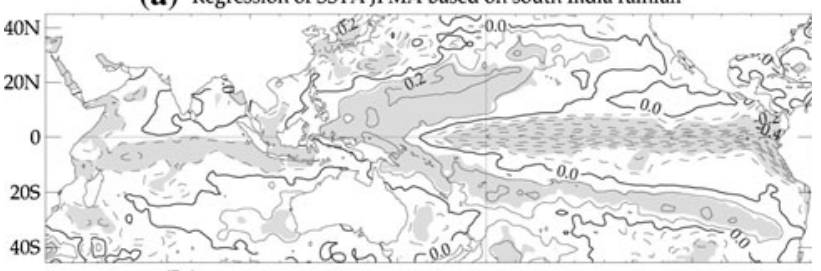

(b) Regression of SSTA JFMA based on December Nino34

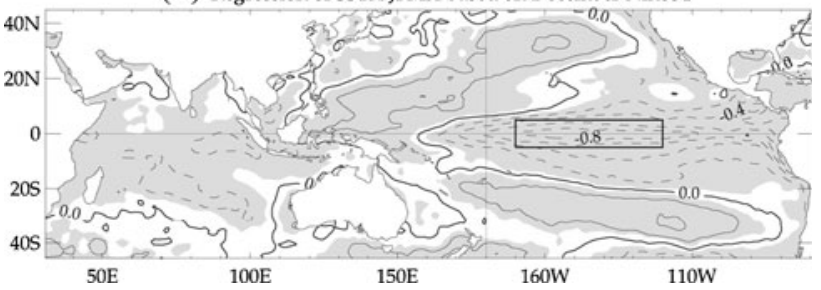

Fig. 10 a Regression of seasonal January-April SST anomalies with interannual anomalies of January-April rainfall over land in south peninsular India, south of $12^{\circ} \mathrm{N}$ (the contour interval is $.1^{\circ} \mathrm{C}$ with dashed contours for negative values; the shading shows area where the regression coefficient is significantly different from zero at the 95\% confidence level). The IMD gridded rainfall product was used, but similar results are obtained with GPCP over the SISL region). b Regression of seasonal January-April SST anomalies with average Nino3.4 (region outlined in b) SST anomalies during previous December (the contour interval is $.2^{\circ} \mathrm{C}$ with dashed contours for negative values; the shading shows area where the regression coefficient is significantly different from zero at the $95 \%$ confidence level). Both regressions are performed over the 1982-2007 period with respect to normalized indices (of standard deviation equal to 1). The sign of the regression in $\mathbf{b}$ has been changed in order to allow an easier comparison with a. The Nino34 region $\left(120^{\circ} \mathrm{W}-170^{\circ} \mathrm{W}, 5^{\circ} \mathrm{N}-\right.$ $5^{\circ} \mathrm{S}$ ) is indicated on $\mathbf{b}$

monsoon over the Ghats as discussed by Vecchi and Harrison (2004), with opposite phase on the year before and after the El Niño peak (Fig. 11a, d). After the peak of El Niño, in agreement with the scenario proposed by (Izumo et al. 2008), the rainfall anomaly is positive over the Ghats, as described in Vecchi and Harrison (2004). The opposite phase observed the previous year is probably linked to the biennial nature of the interannual variability over the Indian Ocean (Meehl et al. 2003). In October-November before its peak, El Niño is associated with increased rainfall over SISL, as discussed in Ropelewski and Halpert $(1987,1989)$ and Zubair and Ropelewski (2006). 
But there is also a significant signal outside of the monsoon period. Figure 11c confirms that an El Niño peak is followed by deficient rainfall (and La Niña with excess rainfall) over the southern tip of India and Sri Lanka from January to April. Figure 12 shows the seasonal variations of the regression coefficients of the average GPCP rainfall over SISL $\left(72^{\circ} \mathrm{E}-82^{\circ} 30^{\prime} \mathrm{E}, 5^{\circ} \mathrm{N}-\right.$ $12^{\circ} 30^{\prime \prime} \mathrm{N}$ ) with the December Niño3.4 normalized index. The strongest correlation with ENSO over that region is during the northeast monsoon, in October-November, as reported in Ropelewski and Halpert $(1987,1989)$ and Zubair and Ropelewski (2006). Despite much weaker climatological rainfall in January-February, the correlation found in this paper is almost as strong. The JanuaryFebruary typical accumulated rainfall anomaly is $5.4 \mathrm{~cm}$ per anomalous standard deviation in Niño3.4 (Fig. 12a); for an average rainfall of $12 \mathrm{~cm}$ (Fig. 12b), i.e. almost $50 \%$ of the mean rainfall. Therefore, relative to the mean rainfall, the influence of ENSO in this season is strong. In absolute terms, it is almost as strong as the signal in October-November.

Figure 13a shows a scatterplot between southern Indian monthly rainfall and Niño3.4 SSTA interannual anomalies during January-April. This scatterplot reveals two interesting points. First there is an asymmetry between the impact of El Niños and La Niñas. This is easily

(a) Rainfall JJAS (-1)

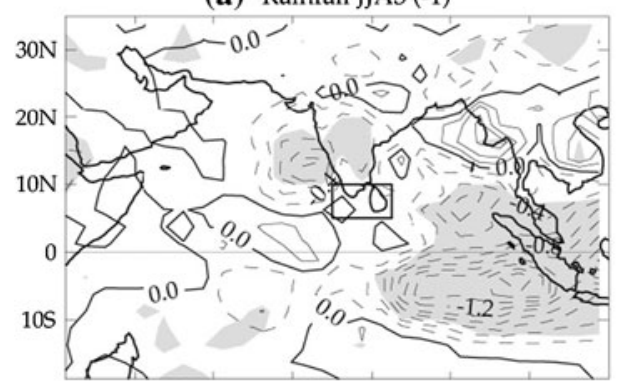

(c) Rainfall JFMA (+1)

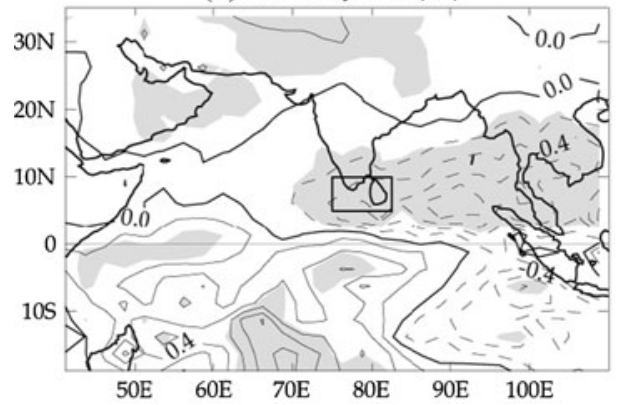

Fig. 11 Maps of linear regression of seasonal rainfall with El Niño (contours every $.2 \mathrm{~mm} \mathrm{day}^{-1}$ with dashed contours for negative values, i.e. decreased precipitations during an El Niño; the shading shows area where the regression coefficient is significantly different from zero at the $95 \%$ confidence level), a June-September (before El Niño peak), b October-November (before El Niño peak), c January- understandable. The climatological rainfall at this season is quite low (about $30 \mathrm{~cm}$ in total from January to April) and there's thus a lower limit to the deficit rainfall anomalies associated with El Niños. On the other hand, La Niñas can have a larger impact on excess rainfall. However, there is a larger spread in rainfall anomalies for negative Nino3.4 SST anomalies, probably due to the high level of internal variability inherent to rainfall dynamics. However, most of the significant $(>1$ std) excess rainfall anomalies are associated with cold Pacific SST anomalies while most of the deficit rainfall occurs with warm Niño3.4. La Niña (El Niño) thus seems to be a necessary condition for increased (reduced) rainfall over SISL in winter/spring, but not a sufficient one.

We summarize our main points in this section: (1) El Niños are associated with decreased rainfall over India and Sri Lanka during JFMA; (2) La Niñas have the opposite effect, but with a stronger amplitude. In the following section, we will test the potential influence of local SST anomalies in the Indian Ocean on JFMA rainfall over the SISL region.

\subsection{Indian Ocean SST influence}

One must be careful and not attribute entirely the changes of rainfall over SISL to SST changes in the tropical Pacific. (b) Rainfall ON (-1)

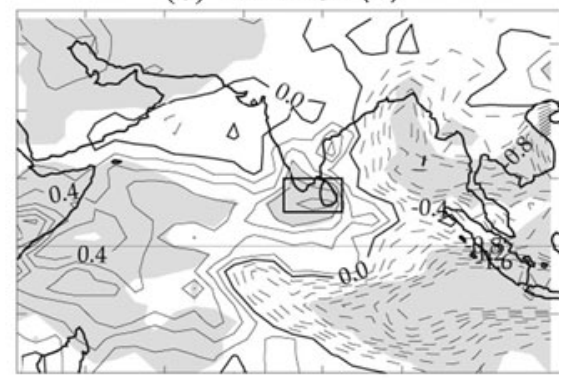

(d) Rainfall JJAS (+1)

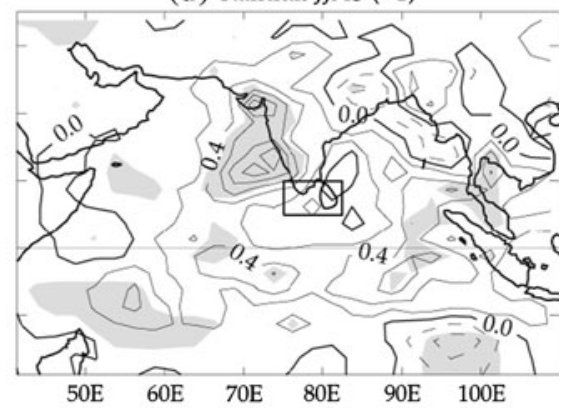

April (just after El Niño peak), d June-September (after El Niño peak). The regression is performed with respect to the normalized (standard deviation equal to 1) December Niño3.4 SST anomaly. The $72^{\circ} \mathrm{E}-82^{\circ} 30^{\prime} \mathrm{E}, 5^{\circ} \mathrm{N}-12^{\circ} 30^{\prime} \mathrm{N}$ region encompassing South India and Sri Lanka is indicated for future reference 


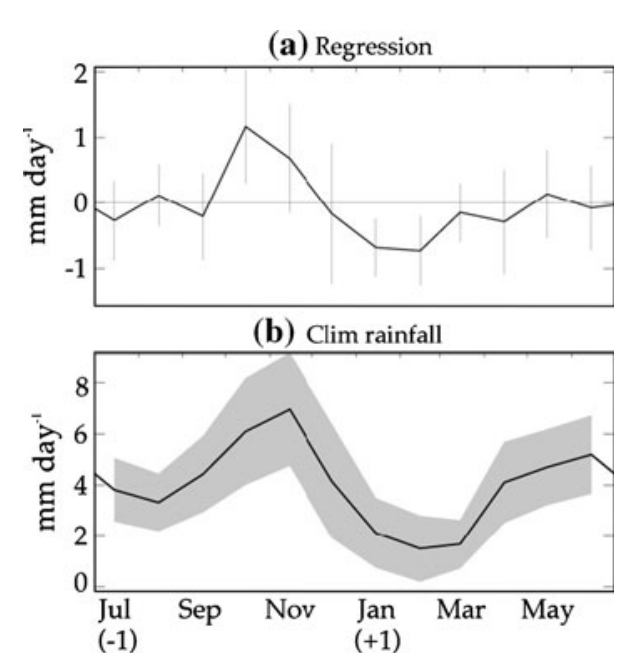

Fig. 12 a Time series of the regression coefficient $\left(\mathrm{mm} \mathrm{day}^{-1}\right)$ between monthly seasonal GPCP rainfall over the $72^{\circ} \mathrm{E}-82^{\circ} 30^{\prime} \mathrm{E}$, $5^{\circ} \mathrm{N}-12^{\circ} 30^{\prime} \mathrm{N}$ region encompassing South India and Sri Lanka (outlined in Fig. 8) and El Niño. The regression is performed with respect to the normalized (standard deviation equal to 1) December Niño3.4 SST anomaly. b Time series of rainfall $\left(\mathrm{mm} \mathrm{day}^{-1}\right)$ climatology over the same region with shading showing \pm one standard deviation of seasonal rainfall. The monthly seasonal rainfall anomaly is estimated as the monthly average of 90 day low-passed filter daily rainfall anomalies with respect to the mean seasonal cycle

Several modelling studies suggest that the SST changes associated with ENSO in the tropical Indian Ocean (that are persistent until August the following year at least) can also have an impact regionally (e.g. Watanabe and Jin 2003; Annamalai et al. 2005; Xie et al. 2009). La Niña (El Niño) induces a cooling (warming) over the Indian Ocean in spring, in particular in the $0-10^{\circ} \mathrm{S}$ band (Fig. 10b; Xie et al. 2009; Du et al. 2009). Figure 10a shows that the surface cooling associated with rainfall anomalies over SISL is more concentrated between 0 and $10^{\circ} \mathrm{S}$ and in the western Indian Ocean. So, while direct atmospheric teleconnections with the Pacific Ocean could drive some of the rainfall changes over the SISL region, the change in meridional distribution of SST could also play some role, as suggested from the 2008 case in Sect. 3 or by Shankar et al. (2007). We have thus constructed an index of the interhemispheric SST gradient anomaly on the basis of Fig. 10a, by taking the SST anomaly difference between the $75^{\circ} \mathrm{E}-105^{\circ} \mathrm{E}, 8^{\circ} \mathrm{S}-0^{\circ}$ and $65^{\circ} \mathrm{E}-100^{\circ} \mathrm{E}, 10^{\circ} \mathrm{N}-20^{\circ} \mathrm{N}$ boxes.

In addition to the potential influence of the meridional SST gradient anomaly, we have also tested the potential influence of well-established sensitive regions in the Indian Ocean: the JFMA South Western Indian Ocean (with the same definition as in Annamalai et al. 2005), and the Indian Ocean dipole (by using the September-November averaged DMI index, as defined in Saji et al. 1999). Behera and Yamagata (2001) also discuss a subtropical dipole in SST, which peaks at about the same time (February-April), as the one considered in the present study (JFMA). Hence, we also tested its potential impact on rainfall over India, by using the February-April average of the index defined in Behera and Yamagata (2001).

The subtropical dipole of Behera and Yamagata (2001) is not related to rainfall anomalies over SISL in JFMA (correlation of -0.01 ; see Table 1). The IOD index is weakly correlated with SISL JFMA rainfall $(-0.27$, significant at $80 \%$ level; see Table 1 ). This could be expected since the IOD peaks in October but the anomalies in the eastern IO-that contribute most to the DMI-have receded by December and hence cannot affect the JFMA rainfall over India. The weak observed negative correlation $(-0.27)$ probably arises because of the tendency of the IOD to co-occur with ENSO (e.g. Yamagata et al. 2004).

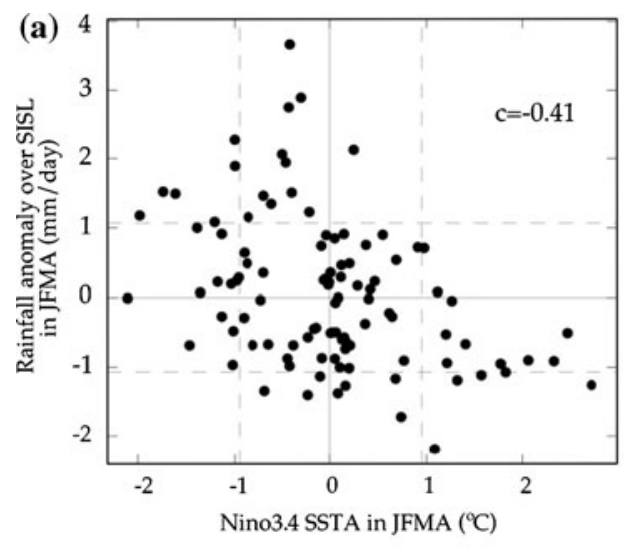

Fig. 13 a Scatterplot of January to March monthly rainfall anomalies over the $72^{\circ} \mathrm{E}-82^{\circ} 30^{\prime} \mathrm{E}, 5^{\circ} \mathrm{N}-12^{\circ} 30^{\prime} \mathrm{N}$ region encompassing South India and Sri Lanka (outlined in Fig. 8) $\left(\mathrm{mm} \mathrm{day}^{-1}\right)$ against monthly SST anomaly over the Niño3.4 region. b Scatterplot of January to March monthly precipitation anomalies over the same

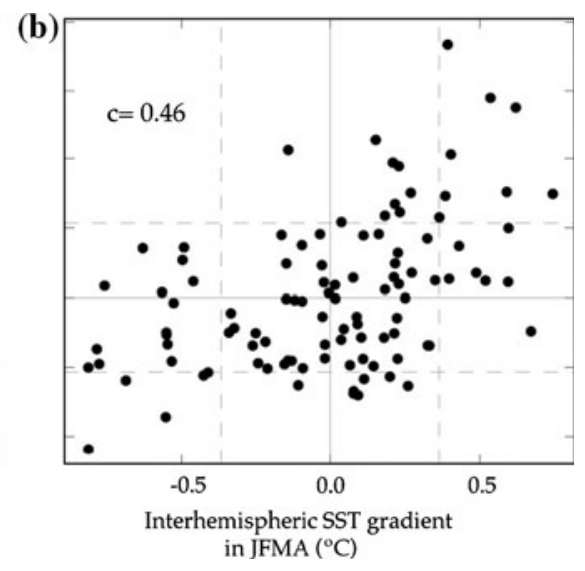

region $\left(\mathrm{mm} \mathrm{day}^{-1}\right)$ against monthly SST meridional gradient over the Indian Ocean (defined as in Fig. 4). Note that this plot is based on monthly average data rather than JFMA averages, explaining the slightly lower correlations than those given in Table 1 
The SST in the southwestern Indian Ocean is more strongly correlated to JFMA rainfall over SISL ( -0.38 significant at $94 \%$ significance level) than the IOD, but its influence is weaker that of ENSO (-0.46 correlation, significant at the $98 \%$ confidence level). On the other hand, the interhemispheric SST gradient has the strongest correlation with the JFMA SISL rainfall (0.55, significant at the 99\% confidence level). The southern box (SST anomalies in the $10^{\circ} \mathrm{S}-0^{\circ}$ band) is the most important for influencing rainfall over SISL at this season, as demonstrated by Fig. 10a and Table 1 (the southern box has a correlation of -0.41 whereas the northern box has only a correlation of 0.16 ). Sensitivity tests further indicate that our results are not overly sensitive to the zonal extension of the box, as long as it includes the region situated south of the Bay of Bengal (not shown). Hence, we obtained the clearest association with SISL rainfall in JFMA (and a plot much similar to Fig. 11c) when considering SST in $0-10^{\circ} \mathrm{S}$ or the interhemispheric gradient of SST. This is further illustrated by Fig. 13b, which suggests that a warmer northern Bay of Bengal/cooler southeastern equatorial ocean favours increased rain over southern India in JFMA. Interestingly, this scatterplot displays the same asymmetry than Fig. 13a (i.e. negative rainfall anomalies are saturated).

The SISL rainfall is slightly more correlated with this cross-equatorial gradient (0.55) than with Niño3.4 (-0.46). However, computing the $95 \%$ significance interval on correlation (either using Fisher's $z$ transformation or by using a Monte-Carlo method on a subset of years) on either simple or partial correlations shows that this difference in correlation is not significant at the $90 \%$ level. This indicates that one cannot determine from simple statistical analysis of the dataset which of these two effects (remote forcing of El Niño or local SST in the Indian ocean) has the strongest impact on SISL rainfall in January-April. We will discuss this point further in Sect. 5.

\section{Summary and discussion}

Most previous studies looking for teleconnections between rainfall over India and SST anomalies have understandably focused on the two monsoon seasons. Here, motivated by a large rainfall anomaly over south India in March 2008, we explored the source of the episodic rain events affecting the southern Indian states and Sri Lanka during the dry JFMA season. We find that, as during summer months, the rain events during that period occur in pulses of 20-30 day duration, revealing an intraseasonal modulation of the precipitation. We find that such intraseasonal pulses of rain tend to be associated with equatorial eastward propagation characteristic of the Madden Julian Oscillation, and that the active phase of the MJO over the Indian Ocean tends to be associated with increased rainfall. In addition to this intraseasonal modulation of the rain, there is an interannual variability of the rain over SISL that is significantly correlated with ENSO. This statistical relation (correlation of 0.46 , significant at the $98 \%$ level) is of roughly the same amplitude as the one for the northeast monsoon (Ropelewski and Halpert 1987, 1989; Zubair and Ropelewski 2006; Kumar et al. 2007), but has opposite sign (compare Fig. 8b, c). Rainfall anomalies over the SISL region are also associated with Indian Ocean SST anomalies, and in particular with the inter-hemispheric SST gradient anomaly (correlation of 0.55 , significant at the $99 \%$ level). Differences in simple and partial correlation of SISL rainfall with ENSO and local Indian Ocean SST are not statistically significant. The influence of the MJO and interannual anoamlies are asymmetric with MJO active phases/La Niñas/cold SST south of the equator resulting in larger anomalies than MJO break phases/El Niños/warm SST anomalies south of the equator (probably because the low climatological rainfall average during this season imposes a strong constraint on the maximum amplitude of negative rainfall anomalies).

Table 1 The first line of the table indicates the standard deviation of JFMA rainfall over south India and Sri Lanka (SISL region)

\begin{tabular}{llr}
\hline & Std & $r$ (significance) \\
\hline JFMA rainfall over SISL & $113 \mathrm{~mm}$ & $1(100 \%)$ \\
Asymmetric mode of rainfall variability (Wu et al. 2008) & 1 & $-0.62(99.9 \%)$ \\
Interhemispheric SST gradient & $0.32^{\circ} \mathrm{C}$ & $0.55(99 \%)$ \\
SST in northern hemisphere & $0.22^{\circ} \mathrm{C}$ & $0.16(55 \%)$ \\
SST in southern hemisphere & $0.33^{\circ} \mathrm{C}$ & $-0.41(96 \%)$ \\
ENSO index & $1.32^{\circ} \mathrm{C}$ & $-0.46(98 \%)$ \\
SST in SWIO & $0.33^{\circ} \mathrm{C}$ & $-0.38(94 \%)$ \\
IOD index & $0.7^{\circ} \mathrm{C}$ & $-0.27(81 \%)$ \\
Subtropical dipole index & $0.82^{\circ} \mathrm{C}$ & $-0.01(5 \%)$ \\
\hline
\end{tabular}

The following lines indicate the standard deviation of various climatic indices (see text for details) and their correlation to JFMA rainfall over the SISL region. The statistical significance computed from a $t$ test is also indicated between brackets 


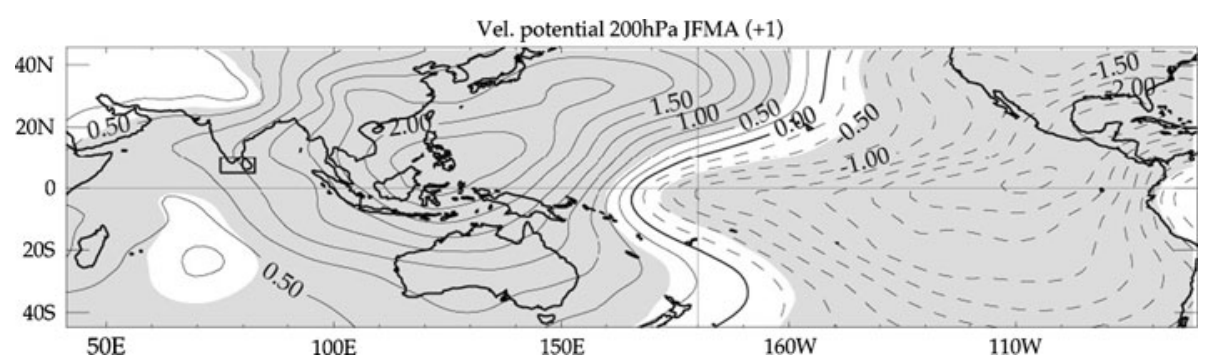

Fig. 14 Map of linear regression of January-April (just after El Niño peak) velocity potential seasonal anomalies at $200 \mathrm{hPa}$ (a proxy for the Walker circulation) with respect to normalized Nino3.4 SST anomalies in December (contours every $.25 \mathrm{~m}^{2} \mathrm{~s}^{-1}$ with dashed contours for negative values, i.e. decreased precipitations during an El Niño; the shading shows area where the regression coefficient is significantly different from zero at the $95 \%$ confidence level)
To our knowledge, no earlier study has before investigated the Indian rainfall teleconnections during winter/ spring in such detail before. Other studies, however, also provide hints that decaying El Niños/La Niñas have a signature over southern India and Sri Lanka. The composite analysis of OLR or rainfall (Fig. 3 from Watanabe and Jin 2003; Fig. 5b from Annamalai et al. 2005; Fig. 12.3c, d from Lau and Wang 2006) suggest, as does our study, that $\mathrm{El}$ Niños (La Niñas) induce reduced (increased) convection/rainfall over south India and Sri Lanka during late winter and spring. The studies that are however most clearly related to ours are those of Wu et al. (2008) and Xie et al. (2009). Although they look at a slightly different period (March-May) and their large scale rainfall pattern does not show clear rainfall anomalies over land in the SISL box, the SISL rainfall variability during JFMA is clearly linked to their asymmetric rainfall pattern. Indeed, there is a -0.62 correlation (significant at the 99.9\% level) between JFMA rainfall over SISL and the index defined by Wu et al. (2008). This correlation remains highly significant even if details of the index computation are changed (e.g. taking January-April instead of MarchMay, or changing the period of the dataset from 1979-2005 to 1982-2008). The large scale precipitation anomalies discussed in Wu et al. (2008) and Xie et al. (2009) are therefore associated with rainfall anomalies over the SISL region from January to April.

There are mainly two possible explanations for the statistical relations between January-April SISL rainfall and ENSO/Indian Ocean SST described in this paper. The first one is a direct atmospheric teleconnection from the Pacific ocean, with the Walker circulation changes associated with El Niño/La Niña driving anomalous subsidence or enabling ascendance over India. This is the mechanism that has generally been invoked so far to explain the impact of ENSO on the southwest and northeast Indian monsoons or the decadal changes (e.g. Zubair and Ropelewski 2006; Krishna Kumar et al. 1999). Figure 14 shows a proxy for the changes in the Walker circulation in January-April after the peak of El Niño. There is a modest, but significant, change of the velocity potential over India, with the increased subsidence suggesting a tendency of El Niños (La Niñas) to reduce (enhance) convective activity over the eastern tropical Indian Ocean.

The other possibility is that the remotely-forced changes of SST induced by ENSO over the Indian Ocean also influence convection over southern India. In March 2008, for example, the climatological meridional temperature gradient over the Bay of Bengal had reversed, and warmest temperatures were found in the northern hemisphere in February-March. Knowing the preference of atmospheric convection for high SSTs (e.g. Gadgil et al. 1984; Graham and Barnett 1987), it is quite possible that this would have also helped a northward shift of the ITCZ. The scenario proposed by Xie et al. (2009) is in general in agreement with this hypothesis, and their coupled experiments with positive SST anomalies imposed in the $0-20^{\circ} \mathrm{S}$ band of the Indian Ocean indeed induce dry anomalies over the SISL region (see their Fig. 10d). There are different hypotheses on the physical mechanisms influencing the evolution of this asymmetric SST anomaly, with Du et al. (2009) and Xie et al. (2009) suggesting a strong role of ocean dynamics in the southern tropical Indian Ocean while $\mathrm{Wu}$ et al. (2008) emphasize mostly the role of the wind-evaporation-SST feedback. All these studies, however, suggest the role of local processes in the Indian Ocean in shaping an asymmetric SST anomaly, which is responsible for the asymmetric rainfall pattern that causes anomalies over the SISL region during January-April.

We feel that the correlation of 0.55 (significant at the 99\% level) found between SISL rainfall and interhemispheric SST gradients provides a motivation for further study of the potential role of local SST anomalies in the Indian Ocean. During a La Niña, there is slightly increased ascendance over southern India but the remotely driven cold SSTs south of the equator could be the main factor that favouring an episodic northward movement of the ITCZ. A description of the exact mechanisms at work for 
explaining the SISL rainfall teleconnections is beyond the scope of this study and will probably need a future specific modelling study.

Intraseasonal variability has often been referred to as the "building block" of the monsoon interannual variability (Webster et al. 1998). Figure 4b indeed suggests that the bulk of the March 2008 rainfall anomaly occurs as a large rainfall pulse associated with an active phase of the MJO over the Indian Ocean sector. We think that there may indeed be a strong interaction between the intraseasonal and interannual timescales, with, for example, an anomalous interhemispheric SST gradient over the Indian Ocean favouring farther northward penetration of the MJO in winter-spring 2008. It is, however, difficult to demonstrate this from the observational records (selecting cases with significant interannual anomalies restricts severely the number of samples of intraseasonal variability and does not allow significant statistics). Whether the meridional SST gradient in this season modulates the northward penetration of intraseasonal variability could however be studied with the help of atmospheric general circulation model experiments.

Most of the existing studies or forecasting schemes for Indian rainfall have up to now understandably focused on the southwest and northeast monsoon periods. The present study shows that there are almost as large signals over Sri Lanka and the southern Indian states of Kerala and Tamil $\mathrm{Nadu}$, and that these signals can be linked to external predictors like SST in the Indian Ocean or ENSO. Including the winter and spring months in seasonal rainfall forecasting scheme should therefore improve the prediction of annual integrated rainfall, which might be useful for some water management applications.

Acknowledgments JV did this work whilst at NIO as a visiting scientist, and is funded by Institut de Recherche pour le Développement (IRD). RSN thanks INCOIS/MOES for their support. DS was supported by funding from the Council of Scientific and Industrial Research (CSIR) and Department of Science and Technology (DST). This is NIO publication 4898 .

\section{References}

Annamalai H, Liu P, Xie S-P (2005) Southwest Indian Ocean SST variability: its local effect and remote influence on Asian monsoons. J Climate 18:4150-4167

Behera SK, Yamagata T (2001) Subtropical SST dipole events in the southern Indian Ocean. Geophys Res Lett 28:327-330

Du Y, Xie S-P, Huang G, Hu K-M (2009) Role of air-sea interaction in the long persistence of El Niño-induced North Indian Ocean warming. J Climate 22:2023-2038

Gadgil S, Joseph PV, Joshi NV (1984) Ocean-atmosphere coupling over monsoon regions. Nature 312:141-145

Goswami BN (2005) South Asian monsoon. In: Lau WKM, Waliser DE (eds) Intraseasonal variability in the atmosphere-ocean climate system. Praxis Springer, Berlin, pp 19-55
Graham NE, Barnett TP (1987) Sea surface temperature, surface wind divergence, and convection over the tropical oceans. Science 238:657-659

Huffman GJ, Adler RF, Arkin PA, Chang A, Ferraro R, Gruber A, Janowiak J, Joyce RJ, McNab A, Rudolf B, Schneider U, Xie P (1997) The global precipitation climatology project (GPCP) combined precipitation data set. Bull Am Meteor Soc 78:5-20

Huffman GJ, Adler RF, Morrissey MM, Bolvin DT, Curtis S, Joyce R, McGavock B, Susskind J (2001) Global precipitation at onedegree daily resolution from multisatellite observations. J Hydrometeor 2:36-50

Izumo T, de Boyer Montégut C, Luo J-J, Behera SK, Masson S, Yamagata $T$ (2008) The role of the western Arabian Sea upwelling in Indian monsoon rainfall variability. J Climate 21:5603-5623

Jones C, Carvalho LMV, Higgins RW, Waliser DE, Schemm JKE (2004) Climatology of tropical intraseasonal convective anomalies 1979-2002. J Climate 17:523-539

Joseph PV (1990) Warm pool over the Indian Ocean and monsoon onset. Trop Ocean Atmos Newslett 53:1-5

Kalnay E et al (1996) The NCEP/NCAR 40-year reanalysis project. Bull Am Meteor Soc 77:437-471

Kawamura R, Matsuura T, lizuka S (2001) Role of equatorially asymmetric sea surface temperature anomalies in the Indian Ocean in the Asian summer monsoon and El Niño-Southern Oscillation coupling. J Geophys Res 106:4681-4693

Klein SA, Soden BJ, Lau N-C (1999) Remote sea surface temperature variations during ENSO: evidence for a tropical atmospheric bridge. J Climate 12:917-932

Kripalani RH, Kumar P (2004) Northeast monsoon rainfall variability over south peninsular India vis-à-vis the Indian Ocean dipole mode. Int J Climatol 24:1267-1282

Krishna Kumar K, Rajagopalan B, Cane MA (1999) On the weakening relationship between the Indian monsoon and ENSO. Science 284:2156-2159

Kumar P, Rupa Kumar K, Rajeevan M, Sahai AK (2007) On the recent strengthening of the relationship between ENSO and northeast monsoon rainfall over south Asia. Clim Dyn 28:649-660

Lau NC, Nath MJ (2000) Impact of ENSO on the variability of the Asian-Australian monsoons as simulated in GCM experiments. J Climate 13:4287-4309

Lau NC, Wang B (2006) Interactions between the Asian monsoon and the El Niño/Southern Oscillation. In: Wang B (ed) The Asian monsoon. Praxis Springer, Berlin, pp 479-512

Meehl GA, Arblaster JM, Loschnigg J (2003) Coupled oceanatmosphere dynamical processes in the tropical Indian and Pacific Oceans and the TBO. J Climate 16:2138-2158

Murtugudde R, McCreary JP, Busalacchi AJ (2000) Oceanic processes associated with anomalous events in the Indian Ocean with relevance to 1997-1998. J Geophys Res 105:3295-3306

Nageswara Rao G (1999) Variations of the SO relationship with summer and winter monsoon rainfall over India: 1872-1993. J Climate 12:3486-3495

Rajeevan M, Bhate J, Kale JD, Lal B (2006) A high resolution daily gridded rainfall for the Indian region: analysis of break and active monsoon spells. Curr Sci 91(3):296-306

Rasmusson EM, Carpenter TH (1983) The relationship between eastern equatorial Pacific sea surface temperature and rainfall over India and Sri Lanka. Mon Weather Rev 110:354-384

Revadekar JV, Kulkarni A (2008) The El Niño-Southern Oscillation and winter precipitation extremes over India. Int J Clim 28:1445-1452

Reynolds R, Rayner N, Smith T, Stokes D, Wang W (2002) An improved in situ and satellite SST analysis for climate. J Climate 15:1609-1625 
Ropelewski CF, Halpert MS (1987) Global and regional scale precipitation patterns associated with the El Niño/Southern Oscillation. Mon Weather Rev 115:1606-1626

Ropelewski CF, Halpert MS (1989) Precipitation patterns associated with the high index phase of the Southern Oscillation. J Climate 2:268-284

Saji NH, Goswami BN, Vinayachandran PN, Yamagata T (1999) A dipole mode in the tropical Indian Ocean. Nature 401:360-363

Schott FA, Xie S-P, McCreary JP Jr (2009) Indian Ocean circulation and climate variability. Rev Geophys 47. doi:10.1029/2007RG 000245

Shankar D, Shetye SR, Joseph PV (2007) Link between convection and meridional gradient of sea surface temperature in the Bay of Bengal. J Earth Syst Sci 116:385-406

Shukla J, Paolino D (1983) The Southern Oscillation and the long range forecasting of monsoon rainfall over India. Mon Weather Rev 111:1830-1837

Vecchi GA, Harrison DE (2004) Interannual Indian rainfall variability and Indian Ocean sea surface temperature anomalies. In: Wang C, Xie S-P, Carton JA (eds) Earth climate: the ocean-atmosphere interaction. American geophysical union, geophysical monograph 147, Washington DC, pp 247-260

Vinayachandran PN, Shetye SR (1991) The warm pool in the Indian Ocean. Proc Indian Acad Sci (Earth Planet Sci) 100:165-175

Waliser DE (2006) Intraseasonal variability. In: Wang B (ed) The Asian monsoon. Praxis Springer, Berlin, pp 203-257

Walker GT, Bliss EW (1932) World weather V. Mem R Meteorol Soc 4:53-84

Wang B, Rui H (1990) Synoptic climatology of transient tropical intraseasonal convection anomalies: 1975-1985. Met Atmos Phys 44:43-61

Wang B, Wu R, Fu X (2000) Pacific-east Asian teleconnection: how does ENSO affect East Asian climate? J Climate 13:1517-1536
Watanabe M, Jin F-F (2003) A moist linear Baroclinic model: coupled dynamical-convective response to El Niño. J Climate 16:1121-1139

Webster PJ, Magana VO, Palmer TN, Shukla J, Tomas RT, Yanai M, Yasunari T (1998) Monsoons: processes, predictability and the prospects of prediction. J Geophys Res 103:14451-14510

Webster PJ, Moore AM, Loschnigg JP, Leben RR (1999) Coupled oceanic-atmospheric dynamics in the Indian Ocean during 1997-1998. Nature 401:356-360

Wheeler MC, Hendon HH (2004) An all-season real-time multivariate MJO index: development of an index for monitoring and prediction. Mon Weather Rev 132:1917-1932

Wu R, Kirtman BP, Krishnamurthy V (2008) An asymmetric mode of tropical Indian Ocean rainfall variability in boreal spring. J Geophys Res 113:D05104. doi:10.1029/2007JD009316

Xie S-P, Hu K, Hafner J, Du Y, Huang G, Tokinaga H (2009) Indian Ocean capacitor effect on Indo-western Pacific climate during the summer following El Niño. J Climate 22:730-747

Yamagata T, Behera SK, Luo J-J, Masson S, Jury M, Rao SA (2004) Coupled ocean-atmosphere variability in the tropical Indian Ocean, in earth climate: the ocean-atmosphere interaction. In: Wang C, Xie S-P, Carton JA (eds) Geophysical monograph series, 147. AGU, Washington, DC, pp 189-212

Zhang C (2005) Madden-Julian Oscillation. Rev Geophys 43:RG2003. doi:10.1029/2004RG000158

Zubair L, Ropelewski CF (2006) The strengthening relationship between ENSO and northeast monsoon rainfall over Sri Lanka and southern India. J Climate 19:1567-1575

Zubair L, Rao SA, Yamagata T (2003) Modulation of Sri Lankan Maha rainfall by the Indian Ocean dipole. Geophys Res Lett 30. doi:10.1029/2002GL015639 